\title{
Sedimentation and potential venting on the rifted continental margin of Dronning Maud Land
}

\author{
Xiaoxia Huang ${ }^{1}$. Wilfried Jokat ${ }^{1,2}$
}

Received: 15 March 2016/ Accepted: 19 November 2016/Published online: 29 November 2016

(C) The Author(s) 2016. This article is published with open access at Springerlink.com

\begin{abstract}
The relief of Dronning Maud Land (DML), formed by Middle and Late Mesozoic tectonic activity, had a strong spatial control on the early fluvial and subsequent glacial erosion and deposition. The sources, processes, and products of sedimentation along the DML margin and in the Lazarev Sea in front of the DML mountains have been barely studied. The onshore mountain belt parallel to the coast of the DML margin acts as a barrier to the transport of terrigenous sediments from the east Antarctic interior to the margin and into the Lazarev Sea. Only the Jutul-Penck Graben system allows a localized ice stream controlled transport of material from the interior of DML across its old mountain belt. Offshore, we attribute repeated largescale debris flow deposits to instability of sediments deposited locally on the steep gradient of the DML margin by high sediment flux. Two types of canyons are defined based on their axial dimensions and originated from turbidity currents and slope failures during glacial/fluvial transport. For the first time, we report pipe-like seismic structures in this region and suggest that they occurred as consequences of volcanic processes. Sedimentary processes on the DML margin were studied using seismic reflection data and we restricted the seismic interpretation to the identification of major seismic sequences and their basal unconformities.
\end{abstract}

Xiaoxia Huang

xiaoxia.huang@awi.de

1 Helmholtz-Centre for Polar and Marine Research, Alfred Wegener Institute, Am Alten Hafen 26, 27568 Bremerhaven, Germany

2 Department of Geosciences (FB5), University of Bremen, Klagenfurter Strasse, 28334 Bremen, Germany
Keywords Dronning Maud Land margin - Debris flow deposits · Canyons · Ice streams · Seismic chimneys

\section{Introduction}

The Dronning Maud Land (DML) continental margin is a rifted volcanic margin that is at present glaciated and strongly dissected by submarine canyons (Fig. 1). Processes related to the evolution of this rifted margin have been intensively studied by the acquisition of seismic, gravity and magnetic data over the past three decades (Hübscher et al. 1996; Roeser et al. 1996; Jokat et al. 2003, 2004; Hinz et al. 2004; König and Jokat 2006). However, detailed studies that described seismic morphological features and its relationship with the processes occurring on the margin are scarce investigated. The development of submarine canyons and gravity flows are important geological factors in the transfer of large amounts of sediment onto the deeper ocean floor off continental margins (Masson et al. 2006; Gales et al. 2014; Huang et al. 2014; Huang and Jokat 2016). Various processes control the development of canyon systems (Shepard 1981). Gravity flows, including turbidity currents and debris flows, are thought to play an important role in sediment supply and erosion (Straub and Mohrig 2009). However, the origin of the surface sedimentary processes, canyons, and their relationship with the glaciers on the DML margin are poorly studied.

The objective of this study is to improve understanding of sedimentation processes onshore and offshore of the DML, from source to sink, by analyzing available seismic reflection data and drill sites. We focus on a number of erosional and depositional features including submarine canyons, debris flow deposits, and depocenters in sub 
Fig. 1 Location of study area and available datasets. The background map depicts topography and bathymetry. The black lines represent multichannel seismic lines in the study region. The purple lines in section $A, B, C$ and $D$ are profiles presented in the study. The red stars represent the ODP drilling sites

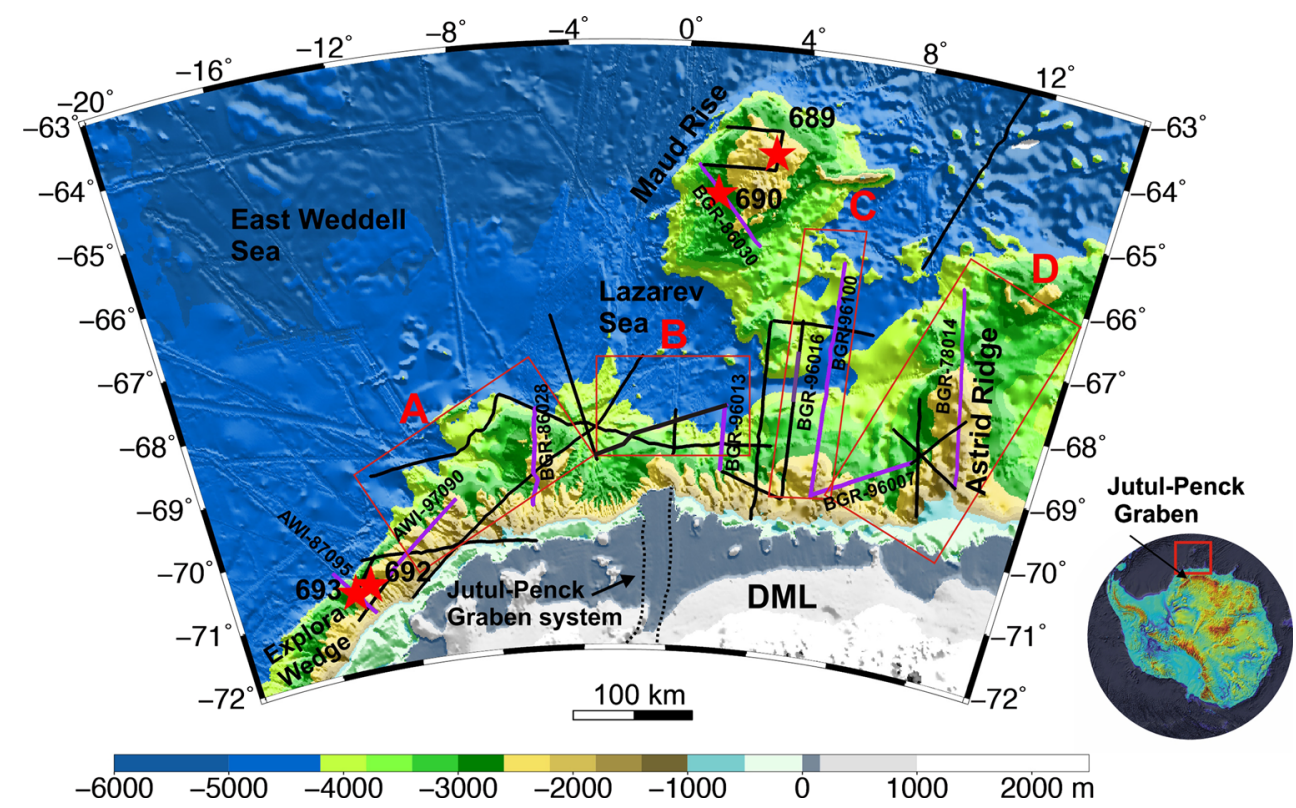

basins on the slope, rise and abyssal plain off southwest DML and in the eastern Weddell Sea and Lazarev Sea (Fig. 1). We link these features to processes of fluvial/ glacial erosion, transport and deposition. Additionally, for the first time here, we report a set of pipe-like features that potentially indicate venting during the evolution of the volcanic margin. Our considerations of sedimentation patterns and the canyon system in relation to the evolution of the Lazarev Sea sheds light on dynamic interactions between the East Antarctic Ice Sheet (EAIS) and sedimentary strata at its bed.

\section{Geological setting}

The continental margins of East Antarctica and East Africa experienced massive rift related volcanism (Jacobs et al. 1996). This volcanism is thought to have been caused by lithospheric extension above a mantle plume (White and McKenzie 1989). The volcanism is well documented onshore in southeastern Africa, but less well so in East Antarctica, where its products have been eroded or overlain by the present-day ice shield. Offshore seismic reflection and refraction data (Hinz et al. 2004; Jokat et al. 2004) confirm that the DML margin can be classified as a volcanic rifted continental margin that formed during the Mesozoic break-up of Gondwana. Volcanic rifted continental margins are commonly characterized by thick wedges of volcanic flows, manifested in seismic reflection data as packages of seaward dipping reflectors (SDRs) with high seismic velocities (Hinz and Krause 1982; Hinz and
Kristofferson 1987; Franke 2013). Two SDR sequences are known from seismic reflection data along the Lazarev Sea margin, and have been interpreted to indicate two-phases of break-up (Hinz et al. 2004).

Plate tectonic reconstructions and seismic refraction data suggest that the final dispersal of DML and SW Africa did not happen before $138 \mathrm{Ma}$, and that the continental margin off DML underwent a complex and long-lived rift history (Jokat et al. 2003, 2004; Eagles and König 2008). In particular, the Lazarev Sea margin was an area of massive volcanism during and after the breakup. A magmatic pulse formed the Maud Rise large igneous province at $65^{\circ} \mathrm{S}, 3^{\circ} \mathrm{E}$ well after breakup. Off the conjugate margin, the volcanic Mozambique Ridge formed by southwards stepwise migration of a volcanic centre (König and Jokat 2010). These processes are currently not understood in great detail, but they have undoubtedly had a strong impact on the structure and geodynamic development of the DML margin and its neighbouring deep-sea basins.

Onshore, the mountain range in central DML trends E$\mathrm{W}$ and is about $200 \mathrm{~km}$ wide, with average elevation of $2000 \mathrm{~m}$. This mountain belt is dissected by the Jutul-Penck Graben system, whose NE-SW-orientated branch is between 20 and $70 \mathrm{~km}$ wide and connects the interior of East Antarctica with the Lazarev Sea margin (Ferraccioli et al. 2005; Riedel et al. 2012; Fretwell et al. 2012). The Jutul-Penck Graben is suggested to be an old tectonic feature, which was reactivated during the Gondwana rift phase (Riedel et al. 2012). Such a tectonic graben is expected to have profound influence on sedimentation pathways and processes along the DML margin. 


\section{Data and methods}

The study ties the stratigraphic framework determined from a few drilling sites into a multi-channel seismic (MCS) network acquired over the course of several RV Polarstern cruises, which were operated by Alfred Wegener Institute (AWI) in 1987, 1990, 1992 and 1997 and by the Federal Institute for Geosciences and Natural Resources (BGR) in 1978, 1986, and 1996 (Fig. 1). During Ocean Drilling Program (ODP) Leg 113, two sites (692 and 693) were drilled on the mid-slope of the southeastern Weddell Sea margin. Site 693 , near $71^{\circ} \mathrm{S}, 14^{\circ} \mathrm{W}$, achieved penetration to a depth of $483.9 \mathrm{~m}$ (Fig. 2B) and recovered a Quaternary to Lower Cretaceous sedimentary sequence, which is largely rich in biosiliceous components. AptianAlbian diatoms are well preserved. Diatom and clay mud are the dominant lithologies of the strata above the Oligocene (Fig. 2B; Kennett and Stott 1990). Two additional sites (689 and 690) are located on Maud Rise. Site 690, with a penetration of $317.0 \mathrm{~m}$, recovered pelagic, biogenic sediments that range in age from lowermost Maastrichtian through Plio-Pleistocene (Fig. 2A). Basalt, classified as olivine alkali ocean basalt, was intersected at Site 690, at 317 mbsf (Kennett and Stott 1990).

Previous seismostratigraphic studies identified a number of prominent unconformities in the Weddell Sea (Miller et al. 1990; Rogenhagen et al. 2004; Huang et al. 2014; Huang and Gohl 2015; Huang and Jokat 2016; Fig. 2). However, it is still challenging to establish whether, and how, the changes responsible for their formation are manifested in the seismic stratigraphy of the Lazarev Sea and along its margin. In addition, the existing stratigraphic model from the Riiser-Larsen Sea (Hinz et al. 2004; Leitchenkov et al. 2008) is difficult to transfer into the study region because of an intervening topographic barrier known as Astrid Ridge (Fig. 1). Interpretation of the sedimentary units in the Lazarev Sea is thus only possible by examination of seismic reflection profiles and a jump correlation from ODP site 693 to section A, a distance of $100 \mathrm{~km}$ (Figs. 1, 3).
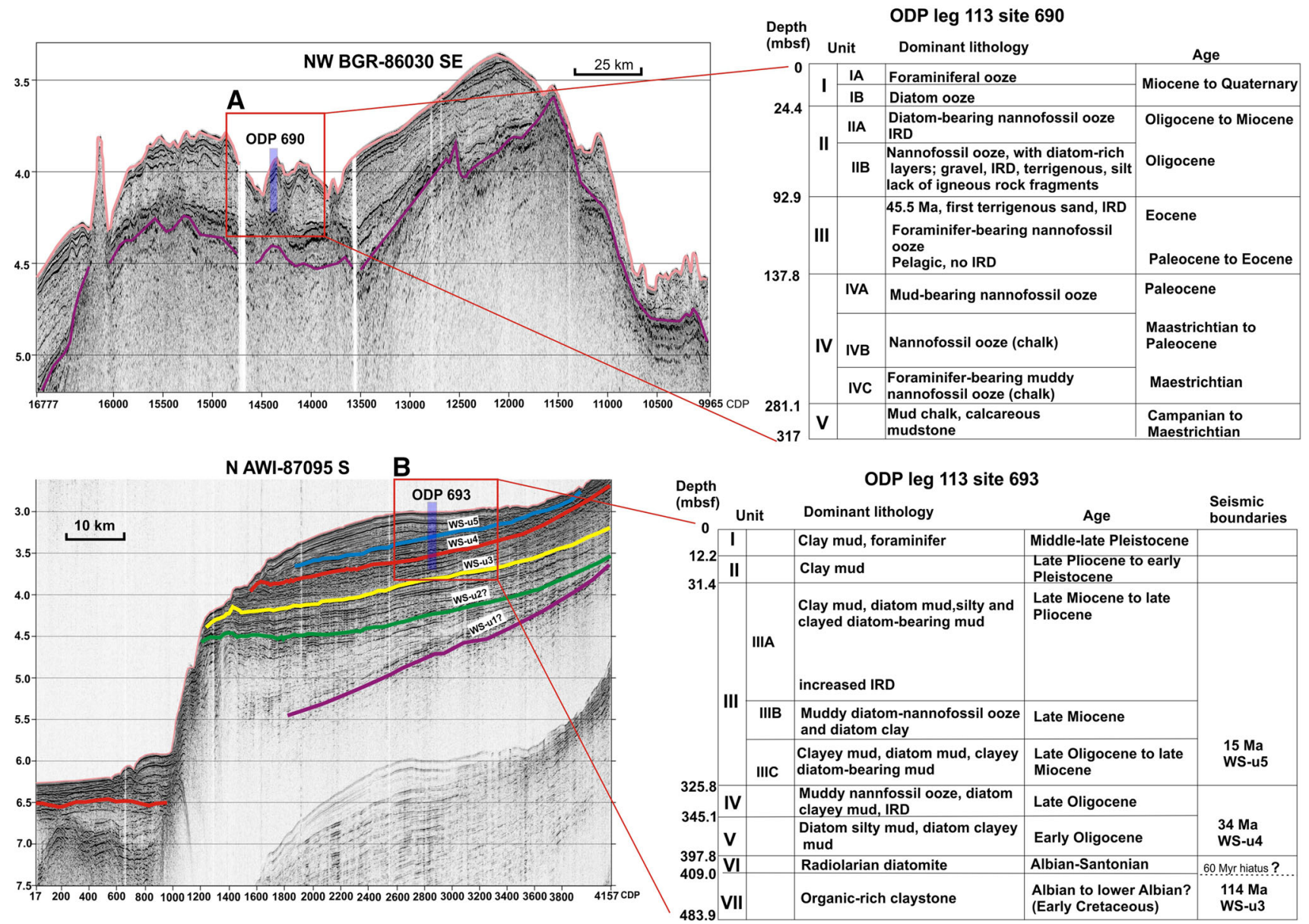

Fig. 2 The locations of ODP 690, 693 on the multichannel seismic lines from DML margin $A$ and Maud Rise $B$. The tables at the right show the recovered dominant lithologies and accompanying age information from the two ODP samples, see Fig. 1 for location 


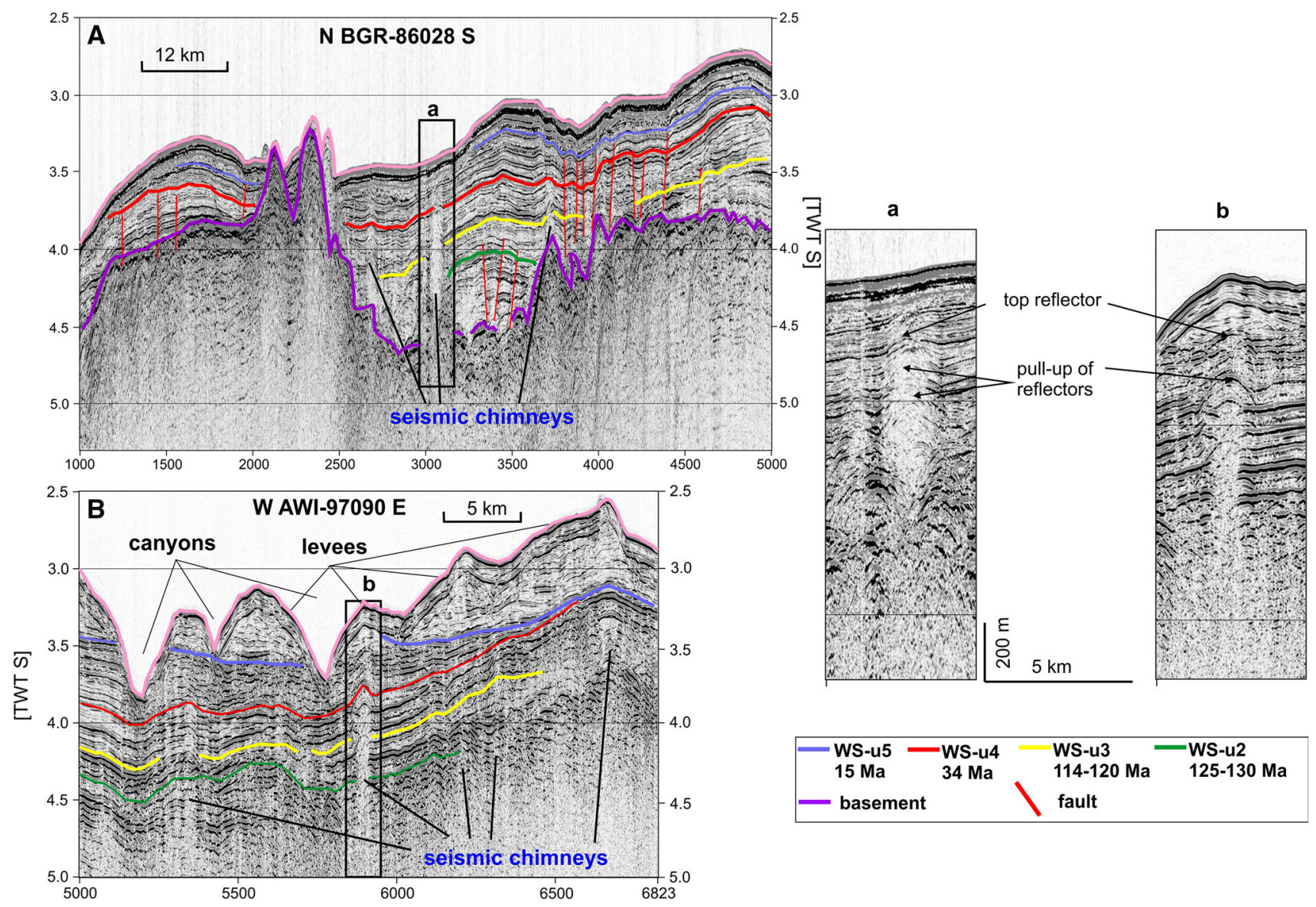

Fig. 3 Examples of pipe-like features, characterized by reflection-poor columns. The pipe-like features are interpreted as seismic chimneys in this study

\section{Results and interpretation}

In our research area, sedimentation is influenced by several dormant tectonic structures (Maud Rise, Astrid Ridge, Explora Wedge/Escarpment). Maud Rise is an oceanic, volcanic structure, which formed at a spreading centre. Drilling on top of this structure (ODP 690, Barker et al. 1988) suggested a Campanian or pre-Campanian basement age, based on the oldest overlying sediment sampled (Fig. 2). Further east, the huge volcanic edifice of Astrid Ridge is recognized by a distinct basement high with an irregular surface in the seismic reflection data (Figs. 1, 7). Aeromagnetic investigations show that the ridge was formed during the initial phase of Gondwana breakup (Leinweber and Jokat 2012) and consists of thickened oceanic crust. The Explora Wedge, occupying much of the continental margin to the SW of Maud Rise, is a thick pile of volcanic rocks that erupted during the initial opening of the Weddell Sea (Hinz and Krause 1982; Jokat et al. 2003; Hinz et al. 2004). The continental margin associated with the wedge's northern reaches features a steep bathymetric escarpment (Fig. 2). The age of the basement was estimated as late Middle Jurassic (Miller et al. 1990; Jokat et al. 2003). More detailed the seismic structures are described in the following four sections (A, B, C and D) as the Fig. 1 demonstrates.

\section{Seismic structures}

\section{Section A: Seismic chimneys}

A number of vertical pipe-like zones of low seismic reflectivity cross the entire sedimentary section on the middle slope at $8-4^{\circ} \mathrm{W}\left(70-72^{\circ} \mathrm{E}\right)$ (Figs. 1,3$)$. The top reflector of each of these features is mound-shaped (Fig. 3A, B). The internal reflection amplitudes within the feature are attenuated, and slightly arched. The flanks of these structures exhibit pull-up reflections (Fig. 3A, B). Such pipe-like features are commonly interpreted as seismic chimneys in seismic records (Planke et al. 2005). Vertical faults are observed on line BGR-86028 to the south of the seismic chimneys in the sedimentary sequence (Fig. 3A). Assuming an average interval velocity of $1800 \mathrm{~m} / \mathrm{s}$, however, the $1500 \mathrm{~m}$ wide seismic chimney ' $\mathrm{a}$ ' 
would be up to $800 \mathrm{~m}$ tall. Most of the seismic chimneys in the study region are similarly wider than they are tall. Another similar type of seismic chimney is observed on the seismic line AWI-97090 (Fig. 3B). Here, the structure terminates upwards at a seismically chaotic unit.

\section{Section B: Debris flows}

The acoustic basement is identified as a strong reflector that can be traced throughout the entire seismic network. Two chaotic units with weakly-reflective or reflection-free seismic facies are recognized and interpreted as debris flow deposits. They occur across the upper continental slope between $0^{\circ}$ and $4^{\circ} \mathrm{E}$ (Fig. 1). One buried debris flow deposit immediately overlies the moderately rugged basement at the upper slope (Fig. 4, CDP: 6000-8836) and is clearly separated from the overlying units by a continuous reflector. This reflector may represent an erosional surface. In the north, the unit overlying this surface is another debris flow deposit (Fig. 4, CDP: 4000-7000). The debris flow deposits reach maximum thicknesses of 200-300 m, and their down-slope extents are about 150-200 km (Fig. 4, BGR-96014). Slump-like features are observed at the tops of the debris flows (Fig. 4, CDP: 4000-7000 between 5 and $5.5 \mathrm{~s}$ TWT). The distal part of the slope on the line BGR-86014 (CDP: 1-4000) is composed of sediments with moderate to well-developed layering depicted in high-amplitude reflections.
Section C: Sub-basins and valley

The $750 \mathrm{~km}$ long N-S trending seismic line BGR-96100 runs across the continental shelf to the deep sea, ending east of Maud Rise (Figs. 1, 5). Based on the seismic reflection characteristics and deep crustal structures, we divide the line into two zones. Zone I (Fig. 5, CDP: 17,000-30,000) has relatively smooth, thick stretched continental crust. Two packages of SDRs are observed in Zone I. The SDRs in the south dip more steeply than those in the north (Hinz et al. 2004; Fig. 4). A thin sediment unit of $0.5 \mathrm{~s}$ TWT is characterized by chaotic high amplitude seismic facies (Fig. 5, CDP: 20,000-26,000, slump) and lies over the lower slope of a moderately-rugged acoustic basement. The acoustic basement of Zone II (Fig. 5, CDP: 1-17,000) is typical of oceanic crust, with its rough surface and strong amplitudes. A noticeable basement valley about $75 \mathrm{~km}$ wide and $2 \mathrm{~km}$ deep is flanked by the Antarctic margin and Maud Rise (Figs. 1, 5, 6). About $2 \mathrm{~s}$ TWT of stratified sediments are deposited in this basement valley. The fill shows remarkable changes in the amplitudes of its parallel reflections between three prominent seismic boundaries (Fig. 6). Further to the north, we observe a sub-basin filled with more than $1 \mathrm{~s}$ TWT (Fig. 5, CDP: 7800-11,500) of sediments that return parallel and subparallel reflections.

The topography becomes very complex towards Maud Rise in the north of the profile (Figs. 1, 5). A seamount rises up from faulted basement to form positive relief on the sea floor and the younger sedimentary strata onlap this

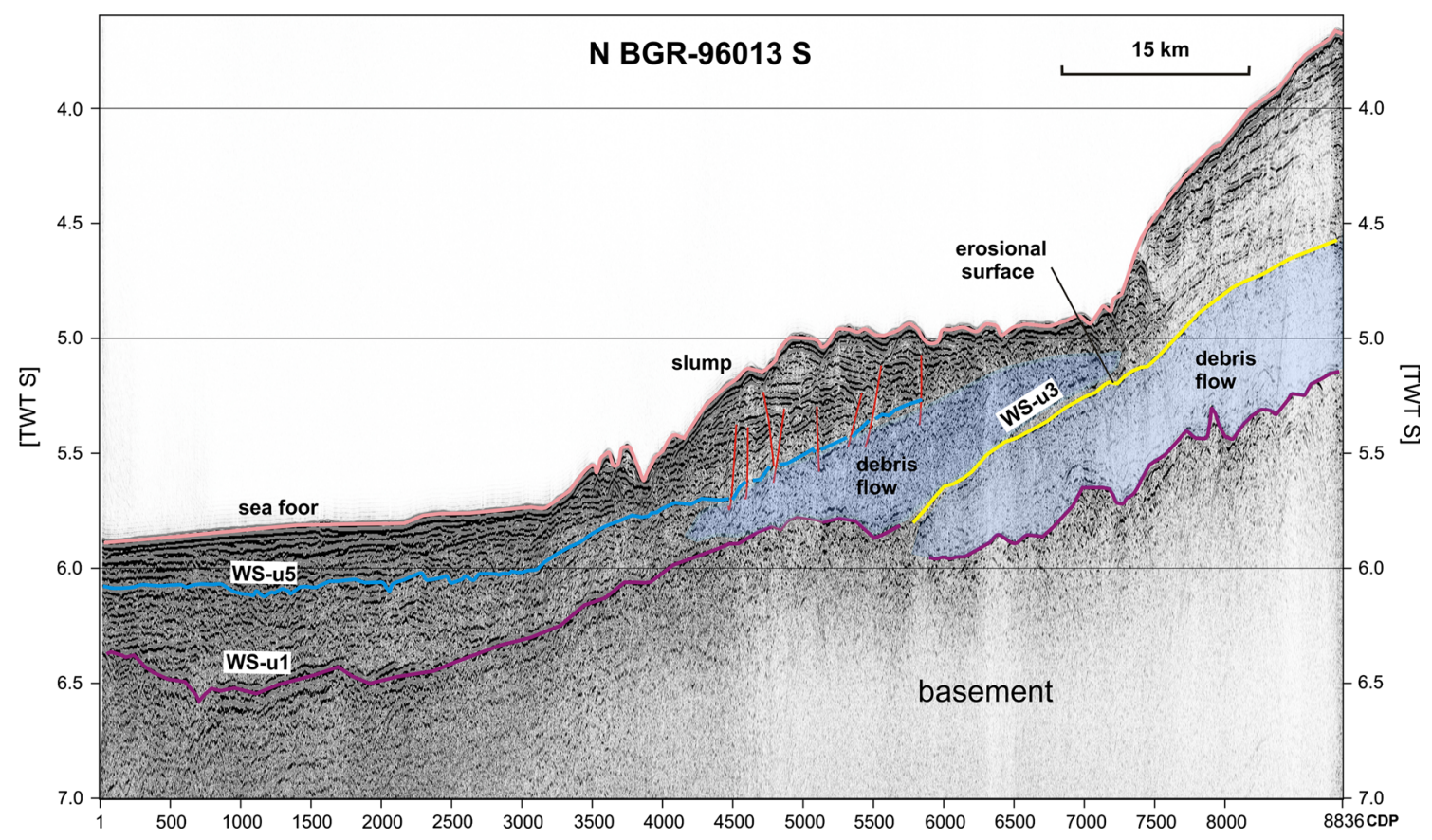

Fig. 4 Interpreted large-scale debris flow deposits and slumps in multichannel seismic data. Red lines signify interpreted growth faults, see Fig. 1 for location 


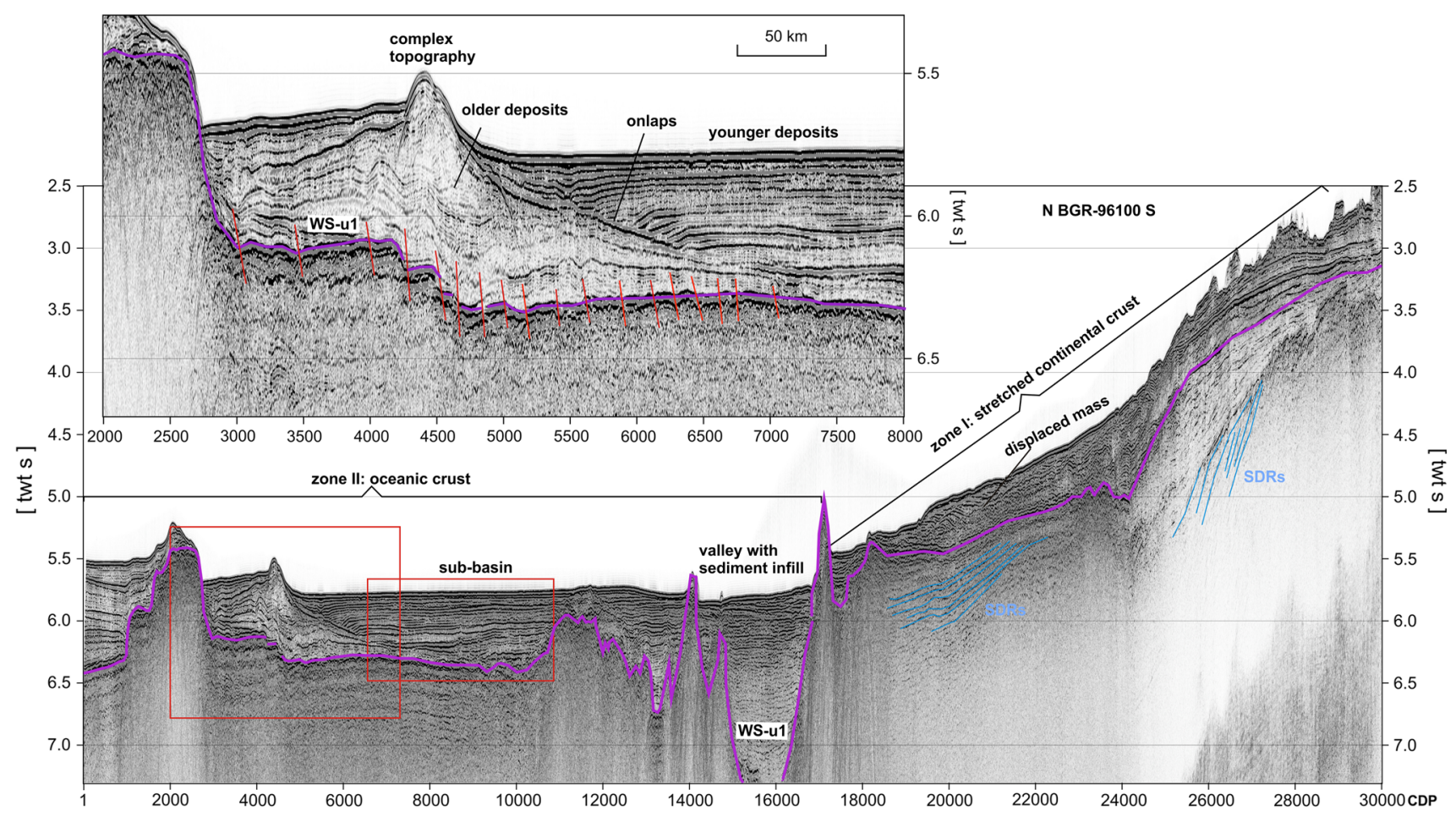

Fig. 5 Multichannel seismic line from the continental slope to the eastern flank of Maud Rise in the Lazarev Sea. The long seismic profile demonstrates sedimentation processes from continental slope

to the deep-sea basins. A Complex topography and abundant normal faults are observed in the acoustic basement. SDRs seaward dipping reflectors, see Fig. 1 for location

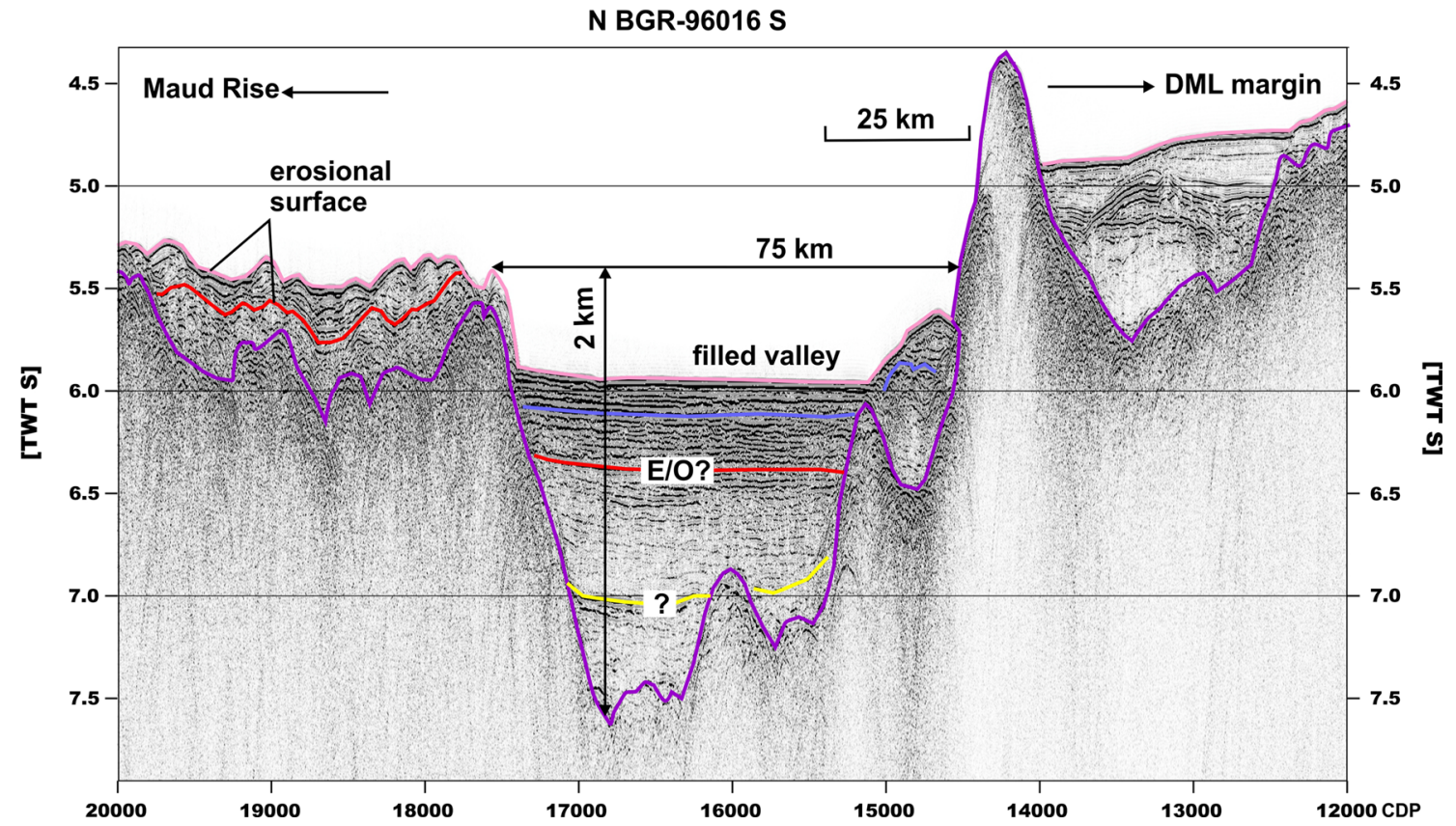

Fig. 6 A filled valley separating Maud Rise from Antarctica. Three unconformities are recognized in the fill sediment strata, see Fig. 1 for location

structure (Fig. 5, CDP: 2000-8000). A prominent sedimentary feature (Fig. 5, CDP: 3000-6500) shows subparallel seismic reflectors with low to medium amplitudes, interbedded with transparent acoustic facies. The reflectors converge southwards and diverge northwards across this structure, leading us to interpret it as a contourite drift that might have formed during the early development of the Weddell Gyre. 


\section{Section D: Canyons at the Astrid Ridge}

The N-S striking Astrid Ridge is located between $9^{\circ} \mathrm{E}$ and $15^{\circ} \mathrm{E}$ off the DML margin. It is characterized by a bathymetric high reaching depths of up to $1500 \mathrm{~m}$ and is prominent as a strongly positive free-air gravity anomaly (Figs. 1, 7). Seismic line BGR-78014 provides an overview of the variation of basement morphology and sedimentation between the ridge's southern end at the continental margin and its northern termination at the oceanic Astrid Fracture Zone. Near the southern end of the ridge, a deep fault-related graben has formed at the basement surface and is filled by sediment (Fig. 7, CDP: 10,500-13,576). A channel levee complex is deposited over the top of the graben fill (Fig. 7; CDP: 9000-13,567). The seafloor depth of the southern part of the Astrid Ridge is about $1500 \mathrm{~m}$, and the sediment thickness can be as much as $1000 \mathrm{~m}$.

Two types of canyons are present along the margin of DML near Astrid Ridge (Figs. 1, 8). Type I canyons are of small size (less than $100 \mathrm{~m}$ deep and of variable width), with levees developed on their flanks (Fig. 8, CDP: 2000-5000). The levees are internally stratified and the strata thin away from the levee crests. This canyon type exhibits smooth, highly aggradational morphologies without any infill. Type II canyons are larger (Fig. 8, CDP: $10,000-12,000$ ), reaching up to $50 \mathrm{~km}$ wide and $500 \mathrm{~m}$ deep, and are bounded by pairs of prominent inter-canyon ridges (Fig. 8, CDP: 8500-10,500). The seismic facies within the inter-canyon ridges and canyon floors are characterized by very chaotic reflections with strong amplitudes. Slump-related terraces are observed on the sidewalls of these Type II canyons (Fig. 8, CDP: 9800-10,500).

\section{Total sediment thickness variations and basement topography}

Acoustic basement can be traced continuously throughout the entire study region (Figs. 2, 3, 4, 5, 6, 7, 9a). The depth of this basement and the thickness of sediments overlying it can be estimated using velocities determined from wideangle data and drilling information. Large uncertainties in basement shape are to be expected in the area of sparse seismic coverage on the shelf.

In general, the seafloor topography varies in sympathy with the basement morphology, such that structural highs appear over basement highs and structural lows are centered over basement lows (Fig. 9a). The total sediment thickness in the study region ranges from 50 to $2000 \mathrm{~m}$ (Fig. 9b) and the volume of sediments in the study region is about $0.1 \times 10^{6} \mathrm{~km}^{3}$. The volumes of the sedimentary units were calculated by applying the GMT routines $\mathrm{grd}$ volume and grdmask to our thickness grids. Two pronounced depocenters are located to the west and east of Maud Rise. North and east of Maud Rise, about $\sim 1300 \mathrm{~m}$ of sediment is accumulated in a sub-basin (Fig. 9b). The sediment thickness overlying Maud Rise varies in the range of $50-500 \mathrm{~m}$, and has been cored as pelagic, biogenic

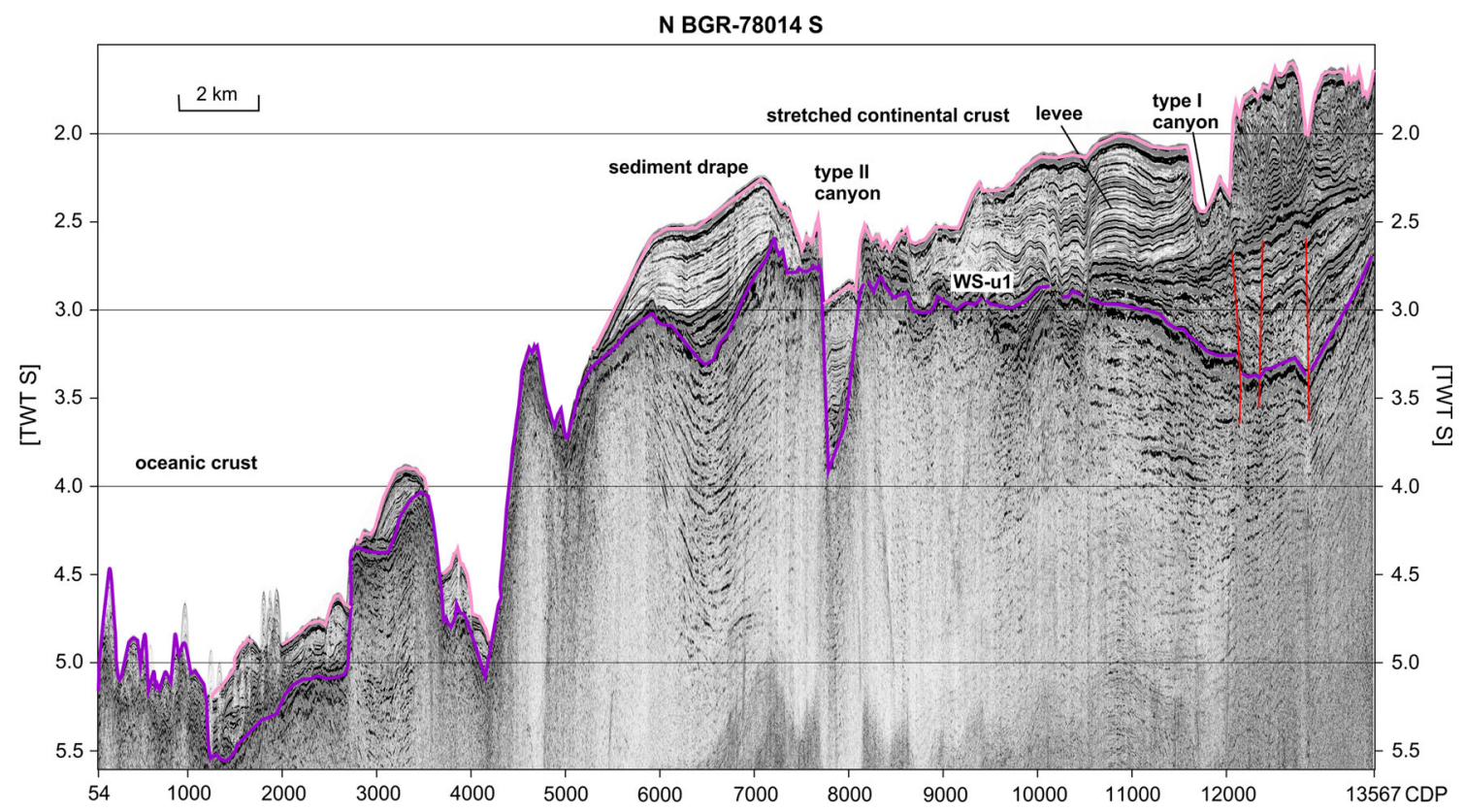

Fig. 7 The interpreted multichannel seismic line BGR-78014 crosses the Astrid Ridge. The line crossed both continental crust (CDP: 4500-13,567) and oceanic crust (CDP: 54-4500), which are situated southward and northward of the Astrid Ridge. Levee and sediment drapes are developed above the stretched continental crust, see Fig. 1 for location 


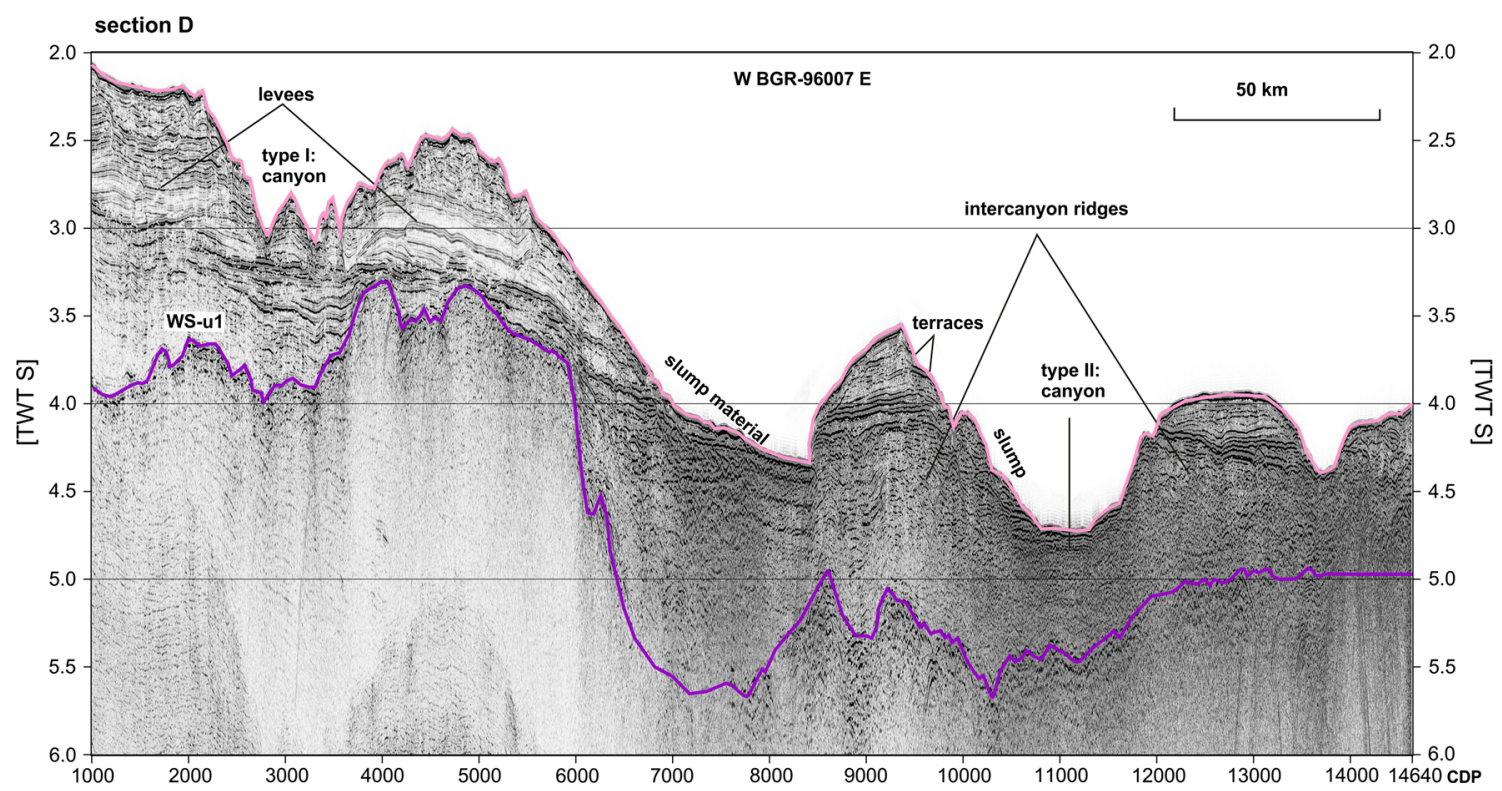

Fig. 8 Two types of canyons with different dimentions and formation mechanisms are distinguished on the multichannel seismic line, west of Astrid Ridge, see Fig. 1 for location

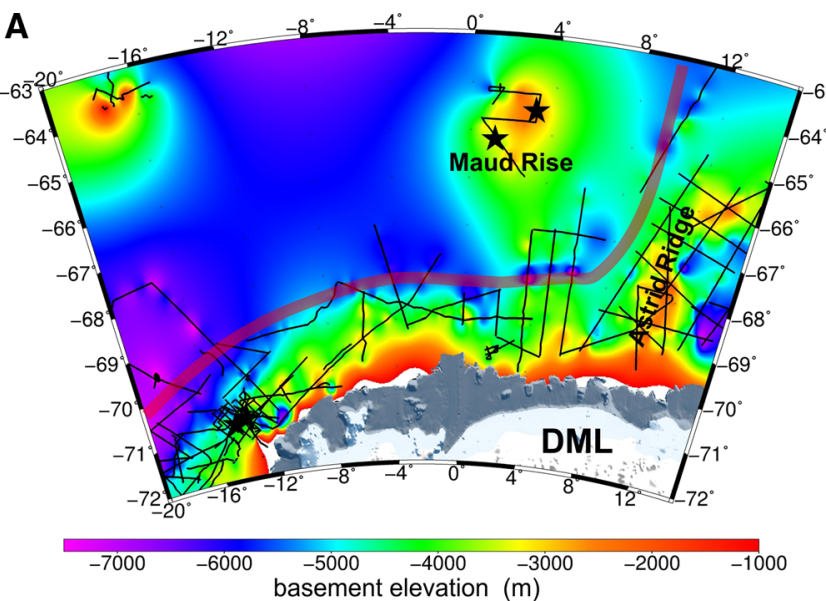

Fig. 9 a Depth to acoustic basement. The thick, dark red curve is a proposed Weddell Gyre pathway between Antarctica and Maud Rise. b Total sediment thickness at the Lazarev Sea and DML margin. The

sediments that range in age from lowermost Maastrichtian through to Plio-Pleistocene (Kennett and Stott 1990; Florindo and Roberts 2005). The valley between Maud Rise and the DML margin has been filled by up to $1500 \mathrm{~m}$ of sediment (Figs. 1, 6, 9, CDP: 15,000-17,000).

\section{Discussion}

\section{Basin sedimentation processes}

Antarctic marginal basins such as those in the Weddell and Riiser-Larsen seas, or off the Wilkes Land margin

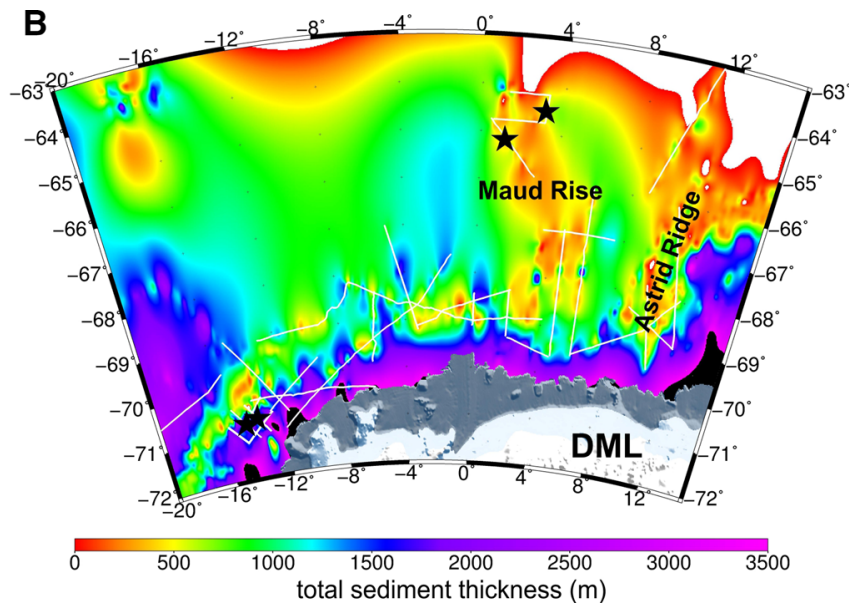

thickness distribution appears to be constrained by basement morphology. Black lines and red stars represent multichannel seismic lines and ODP drilling sites, respectively

and in Prydz Bay, hold vast volumes of glacial sediments that have been delivered to them by (paleo) ice streams with huge drainage catchments (Kuvaas et al. 2004; Close et al. 2007; Leitchenkov et al. 2007, 2008, 2014; Huang et al. 2014). In contrast, only a relatively minor sediment volume, depicted with a maximum thickness of just $1800 \mathrm{~m}$, is preserved in the Lazarev Sea and southwest DML margin (Figs. 8, 9). The limited sediment volume and debris flow deposits resolved by seismic reflection data (Fig. 4) indicate that the slope at the DML margin does not host major submarine fan deposits. Subglacial topography has been interpreted to play an important role in both present-day 
and paleo-ice stream flow (Laymon 1992; Peters et al. 2006) and, therefore, for sediment transport.

The Middle/Late Mesozoic Jutul-Penck Graben system that cuts through the DML mountain belt seems to have allowed only limited or even zero sediment transport to the continental margin from the interior of DML, as the Fig. 10 indicates. We suggest that unlike other drainage basins along Antarctic margins, the major source of sediment for the DML margin was not located in the interior of East Antarctica but was the DML mountain belt itself. Certainly, the local pattern of present-day ice and sediment drainage in the region is mainly controlled by the Jutul-Penck Graben system (Fig. 10). In addition, we infer that expansion of the EAIS exerted strong spatial controls on both early fluvial and subsequent glacial erosion and offshore sedimentation. Particularly, the large debris flow deposits were generated in the study region when the EAIS reached the shelf break. These glacial sediments transported to the shelf break were temporarily stored on the upper slope. Due to the high sedimentation rate, the sediment were unstable, oversteepening or build up excess pore pressure triggered sediment release generating large debris flow deposits (Figs. 4, 10). Furthermore, the DML continental slope contains an intricate network of submarine canyons that on the continental rise develop into a series of channel and overbank deposits of turbidite systems (Figs. 8, 10). We interpret the differences in channel network patterns, channel size result from early tectonic processes and the continental ice sheet feeding glalcial ice streams that reached the outer continental shelf at times of glacial maxima.
Fig. 10 Topography of DML and the Lazarev Sea with major sedimentary and morphological features (after Fretwell et al 2012) Onshore, the DMLmountain belt and Jutul-Penck Graben system, with its ice streams, are observed. Ice streams are adopted from Rignot et al. (2011). Offshore, canyons, debris flow deposits and depocenters are recognized from the seismic reflection data

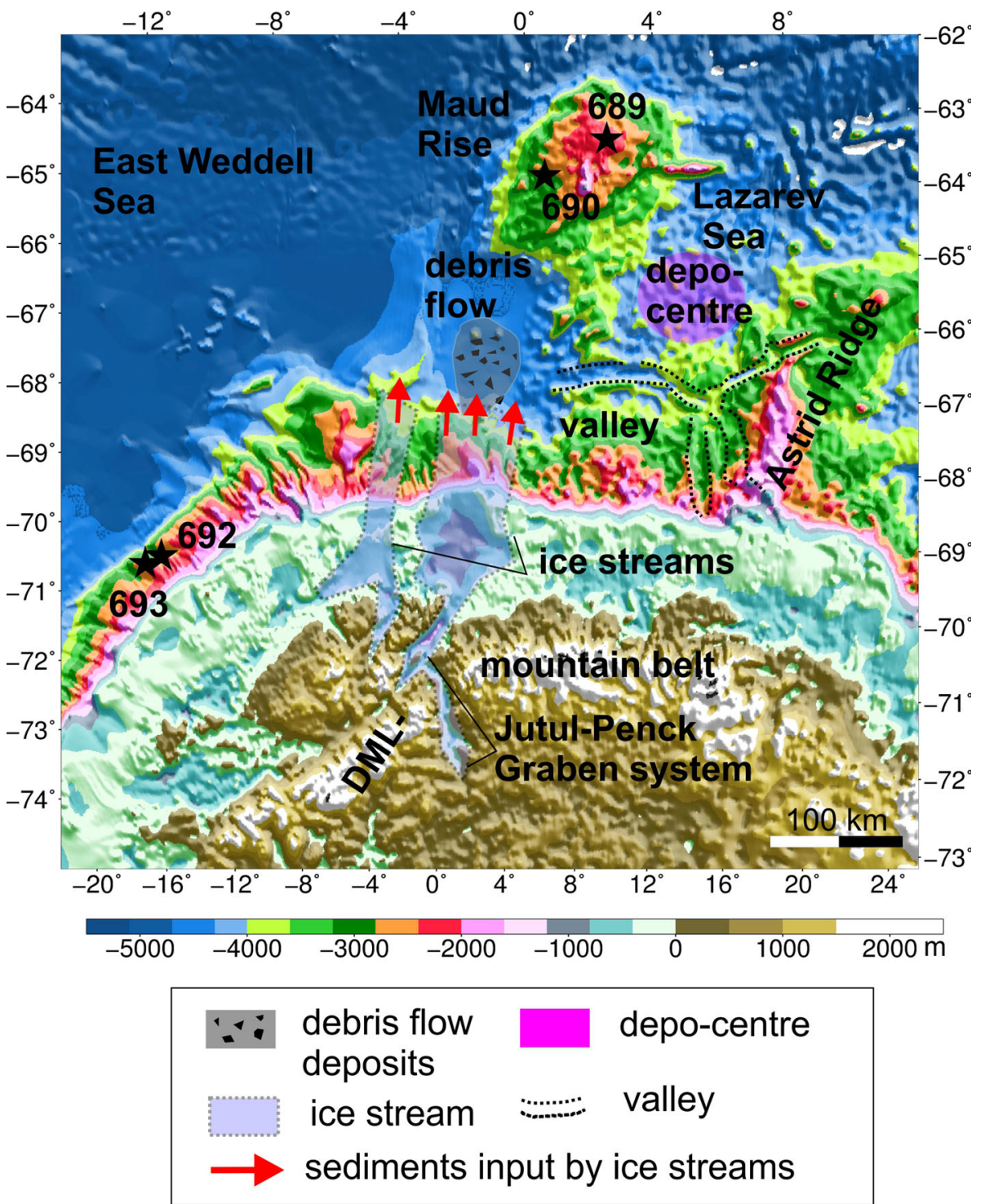


Offshore, our data show large Type II canyons that indent the shelf edge west of Astrid Ridge (Figs. 1, 7; CDP: 10,000-12,000). We attribute the erosive surface in the canyon floors and the numerous slumps and terraces on their sidewalls (Fig. 8) to slope failures. The continuously oversteepened canyon walls are probably the results of downcutting by slope failures or large gravitational flows of Jutul-Penck graben on the DML (Fig. 8). These canyons were eroded and locally filled by coarse-grained material (Fig. 8). Later sediment deposition might also have occurred when the canyon received hyperpycnal flows from the glaciated margin where ice sheets are most erosive. Such high-density flows have the capacity to erode previously-deposited sediments, eventually re-depositing them as turbidites further out in the basin.

The ice drainage system is the source of locally derived coarse-grained glacial outwash at the onset of glaciation (Escutia et al. 2000). Sediments deposited in this phase at ODP 690 (Late Eocene in East Antarctica, Barker et al. 1988; Ehrmann and Mackensen 1992) consist mostly of terrigenous sand, gravel, diamicts, and ice rafted debris (IRD, Fig. 2). Ice streams formed along the pre-existing Jutul-Penck Graben system have acted as the major conduits for transporting a limited amount of terrigenous sediment from the Antarctic continent to the sedimentstarved DML slope.

Our results are in agreement with these concepts. Packages of chaotic reflectors reaching hundreds of meters upslope indicate that the upper part of the margin experienced extensive slumping and debris flow processes (Figs. 1, 4). The debris flow processes possibly concentrated at the continental slope as consequences of ice streams depositing their loads of sediment and melt water at the shelf edge (Figs. 4, 10), or of episodic ice sheet collapse at the shelf break. Large gravity flows can transport material over great distances as they accelerate down the continental slope, eroding earlier unstable sediment on the steeper basin-margin or upper slopes, and spawning new debris flow deposits and slumps (Fig. 4). Therefore, we tentatively suggest that the debris flows primarily formed during times when the Antarctic margin was glaciated. However, the unusually steep topographic gradient (up to $7.5^{\circ}$ ) of the slope off the DML margin would have left it liable to mass transport processes at all times. The steeper the slope, the greater the velocity of sediment gravity flows and, therefore, the greater the sediment discharge to the slope (Huang and Jokat 2016). The welldeveloped Type I canyons on the slope are interpreted to be related to down-slope turbidity currents operating during glacial times (Figs. 1, 8). Debris flows and slumps can also produce turbidity currents, which are invoked to explain the formation of the lateral levee deposits along the canyon flanks (Fig. 8, at Type I).

\section{Indications of potential venting}

This study documents the presence of seismic chimneys on the mid slope of the DML margin between $8^{\circ}$ and $4^{\circ} \mathrm{W}$ for the first time (Fig. 3). Seismic chimneys commonly occur in sedimentary basins, including those at passive volcanic margins, e.g. the Vøring and Møre margin basins, or the Ulleung Bain (Planke et al. 2005; Horozal et al. 2009). Around Antarctica, seismic chimneys have also been observed in basins of the Amundsen Sea and Ross Sea Embayment (Geletti and Busetti 2011; Weigelt et al. 2012). Geletti and Busetti (2011) related seismic chimneys to the presence of gas hydrates, whose presence they interpreted from Bottom-Simulating Reflectors (BSR) in their seismic records in the Ross Sea. In contrast, Weigelt et al. (2012) suggested that the reflection-poor vertical pipe-like structures in sedimentary sequences on the middle shelf of the Amundsen Sea Embayment represent mud-diapirs rising from water-rich sediments, and suggested that their formation has been strongly influenced by glacial/interglacial cycles.

However, our seismic records do not enable interpretation of BSRs or pockmarks, which are fed by fluids migrating upward along faults. According to our stratigraphic model, the mound-shaped reflectors at the tops of the chimneys on the DML margin are overlain by glacial diatom-rich sediments (Figs. 2, 3). This may indicate that the process responsible for the chimneys had ceased before the onset of the glacial regime. Thus, we may exclude the scenario that glacial dewatering resulted in these seismic chimneys at the DML margin.

We suggest that the well-preserved and upward deformed vertical flanks and mounded top reflectors in the seismic chimneys are evidence of venting. Taking into account the large (60 Myr) hiatus in ODP site 693 sampling (Barker et al. 1988) and its correlation with the age model (Fig. 2), the fact that the seismic chimneys seem to originate from the acoustic basement suggests that venting may have commenced at 120-130 Ma. In this context, they are most likely related to active volcanic processes after the breakup of Gondwana (Fig. 3). This assumption is in agreement with Jacobs et al. (1996), who suggested that the continental crust of western DML was heated by regional melts that formed from around $180 \mathrm{Ma}$ until the Early Cretaceous (140 Ma) when the lava pile they produced was eroded again. The scenario is in support of the presence of two sequences of SDRs (Fig. 5), which Hinz et al. (2004) and Jokat et al. (2004), attributed to the presence of volcanic effusive rocks emplaced in a subaerial to shallow marine environment during two phases of break-up (at $\sim 190$ and $140 \mathrm{Ma})$. We conclude therefore, that the formation of the seismic chimneys (Fig. 3) is most likely linked to the intrusion of sills into the basement, prompting 
overpressure by heating pore fluids. The fault system acts as the migration pathways of venting.

\section{Conclusions}

Our seismic data document debris flow deposits at the continental slope and indicate that they are the consequences of ice streams depositing their loads of sediment and melt water at the shelf edge, or of episodic ice sheet collapse at the shelf break. In comparison to other Antarctic sub basins with larger drainage areas, the total sediment thickness and volume observed in the study region are small and submarine fan deposits are not observed. The ice streams of the Jutul-Penck Graben system, which cuts through the DML mountain belt, are the most important conduit for delivery of sediments to the continental margin beyond the mountains, while the DML mountain belt acted as a barrier to terrigenious sediment transport from the east Antarctic interior to the Lazarev Sea.

Two types of canyon are defined based on their dimensions and axial sedimentation processes. Type I, of small size and with well-developed levee deposits, results from turbidity current action during glacial times. Type II canyons are deeper and wider, and exhibit slumps and terraces on their sidewalls, which form the flanks of intercanyon ridges. These features may result from fluvial erosion or slope failure in pre-glacial times.

We reported the presence of pipe-like seismic chimneys at this margin for the first time. Tentatively, we attribute their formation to heating and fluid flow following regional intrusion of melt during the Mesozoic breakup of Gondwana. This new finding will be an important contribution to the Scientific Committee on Antarctic Research (SCAR) Action Group that focuses on 'Cold Seeps and Hydrothermal Vents in the Antarctic'.

\begin{abstract}
Acknowledgements The authors would like to thank the masters, crews and seismic teams of the many ship expeditions to the Weddell Sea who made the acquisition of the data used in this study possible. The German Federal Institute of Geosciences and Resources (BGR) is gratefully acknowledged for their contribution of the used seismic data to the Antarctic Seismic Data Library System (SDLS). Many thanks to Dr. Graeme Eagles his careful reading and discussions of the manuscript before submission. Many thanks to reviewers for their thoughtful comments. X.H. has received a Ph.D. scholarship from the Chinese Scholarship Council (CSC).
\end{abstract}

Open Access This article is distributed under the terms of the Creative Commons Attribution 4.0 International License (http://crea tivecommons.org/licenses/by/4.0/), which permits unrestricted use, distribution, and reproduction in any medium, provided you give appropriate credit to the original author(s) and the source, provide a link to the Creative Commons license, and indicate if changes were made.

\section{References}

Barker PF, Kennett JP et al (1988) In: Proceedings of the ocean drilling program, scientific results Leg 113. Ocean Drilling Program, p 774. doi:10.2973/odp.proc.ir.113.1988

Close DI, Stagg HMJ, O'Brien PE (2007) Seismic stratigraphy and sediment distribution on the Wilkes Land and Terre Adélie margins, East Antarctica. Mar Geol 239(1):33-57

Eagles G, König M (2008) A model of plate kinematics in Gondwana breakup. Geophys J Int 173(2):703-717

Ehrmann WU, Mackensen A (1992) Sedimentological evidence for the formation of an East Antarctic ice sheet in Eocene/Oligocene time. Palaeogeogr Palaeoclimatol Palaeoecol 93(1):85-112

Escutia C, Eittreim SL, Cooper AK, Nelson CH (2000) Morphology and acoustic character of the Antarctic Wilkes Land turbidite systems: ice-sheet-sourced versus river-sourced fans. J Sediment Res 70(1):84-93

Ferraccioli F, Jones PC, Curtis ML, Leat PT, Riley TR (2005) Tectonic and magmatic patterns in the Jutulstraumen rift (?) region, East Antarctica, as imaged by high-resolution aeromagnetic data. Earth Planets Space 57(8):767-780

Florindo F, Roberts AP (2005) Eocene-Oligocene magnetobiochronology of ODP Sites 689 and 690, Maud Rise, Weddell Sea, Antarctica. Geol Soc Am Bull 117(1-2):46-66

Franke D (2013) Rifting, lithosphere breakup and volcanism: comparison of magma-poor and volcanic rifted margins. Mar Pet Geol 43:63-87

Fretwell PT, LaRue MA, Morin P, Kooyman GL, Wienecke B, Ratcliffe N, Fox AJ, Fleming AH, Porter C, Trathan PN (2012) An emperor penguin population estimate: the first global, synoptic survey of a species from space. PLoS One 7:1-11

Gales JA, Leat PT, Larter RD, Kuhn G, Hillenbrand CD, Graham AGC, Jokat W (2014) Large-scale submarine landslides, channel and gully systems on the southern Weddell Sea margin, Antarctica. Mar Geol 348:73-87

Geletti R, Busetti M (2011) A double bottom simulating reflector in the western Ross Sea, Antarctica. J Geophys Res 116:B04101. doi:10.1029/2010JB007864

Hinz K, Krause W (1982) The continental margin of Queen Maud Land, Antarctica: Seismic sequences, structural elements and geological development

Hinz K, Kristofferson Y (1987) Antarctica

Hinz K, Neben S, Gouseva YB, Kudryavtsev GA (2004) A compilation of geophysical data from the Lazarev Sea and the Rijser-Larsen Sea, Antarctica. Mar Geophys Res 25:233-245. doi:10.1007/s11001-005-1319-y

Horozal S, Lee GH, Bo YY, Yoo DG, Park KP, Lee HY, Lee K (2009) Seismic indicators of gas hydrate and associated gas in the Ulleung Basin, East Sea (Japan Sea) and implications of heat flows derived from depths of the bottom-simulating reflector. Mar Geol 258(1):126-138. doi:10.1016/j.margeo.2008.12.004

Huang X, Gohl K (2015) Seismostratigraphic analysis and glacial history of the Weddell Sea Region, Antarctica. In: Lohmann G, Meggers H, Unnithan V, Wolf-Gladrow D, Notholt J, Bracher A (eds) Towards an interdisciplinary approach in earth system science. Springer International Publishing, pp 207-217. doi: 10. 1007/978-3-319-13865-7_22

Huang X, Gohl K, Jokat W (2014) Variability in Cenozoic sedimentation and paleo-water depths of the Weddell Sea basin related to pre-glacial and glacial conditions of Antarctica. Glob Planet Change. doi:10.1016/j.gloplacha.2014.03.010

Huang X, Jokat W (2016) Middle Miocene to present sediment transport and deposits in the Southeastern Weddell Sea, Antarctica. Glob Planet Change 139:211-225. doi:10.1016/j.gloplacha. 2016.03.002 
Hübscher C, Jokat W, Miller H (1996) Crustal structure of the Antarctic continental margin in the eastern Weddell Sea. In: Storey BC, King EC, Livermore RA (eds) Weddell Sea Tectonics and Gondwana Break-up, vol 108. Geological Society Special Publication, London, pp 165-174.

Jacobs J, Kaul N, Weber K (1996) The history of denudation and resedimentation at the continental margin of western Dronning Maud Land, Antarctica, during break-up of Gondwana. Geol Soc Lond Spec Publ 108(1):191-199

Jokat W, Boebel T, König M, Meyer U (2003) Timing and geometry of early Gondwana breakup. J Geophys Res Solid Earth 108(B9). doi: 10.1029/2002JB001802

Jokat W, Ritzmann O, Reichert C, Hinz K (2004) Deep crustal structure of the continental margin off the Explora Escarpment and in the Lazarev Sea, East Antarctica. Mar Geophys Res 25(3-4):283-304. doi:10.1007/s11001-005-1337-9

Kennett JP, Stott LD (1990) Proteus and Proto-Oceanus: ancestral Paleogene oceans as revealed from Antarctic stable isotopic results; ODP Leg 113. In: Barker PF, Kennett JP, et al, Proceedings of ODP Science Results, vol 113, pp 865-880

König M, Jokat W (2006) The Mesozoic breakup of the Weddell Sea. J Geophys Res 111:B12102. doi:10.1029/2005JB004035

König M, Jokat W (2010) Advanced insights into magmatism and volcanism of the Mozambique Ridge and Mozambique Basin in the view of new potential field data. Geophys $\mathrm{J}$ Int 180(1):158-180. doi:10.1111/j.1365-246X.2009.04433.x

Kuvaas B, Kristoffersen Y, Guseva J, Leitchenkov G, Gandjukhin V, Kudryavtsev G (2004) Input of glaciomarine sediments along the East Antarctic continental margin; depositional processes on the Cosmonaut Sea continental slope and rise and a regional acoustic stratigraphic correlation from $40 \mathrm{~W}$ to $80 \mathrm{E}$. Mar Geophys Res 25(3-4):247-263

Laymon CA (1992) Glacial geology of western Hudson Strait, Canada, with reference to Laurentide Ice Sheet dynamics. Geol Soc Am Bull 104(9):1169-1177

Leinweber VT, Jokat W (2012) The Jurassic history of the AfricaAntarctica corridor-new constraints from magnetic data on the conjugate continental margins. Tectonophysics 530:87-101. doi:10.1016/j.tecto.2011.11.008

Leitchenkov GL, Guseva YB, Gandyukhin VV (2007) Cenozoic environmental changes along the East Antarctic continental margin inferred from regional seismic stratigraphy (No. 2007-1047-SRP-005). US Geological Survey

Leitchenkov G, Guseva J, Gandyukhin V, Grikurov G, Kristoffersen Y, Sand M, Aleshkova N (2008) Crustal structure and tectonic provinces of the Riiser-Larsen Sea area (East Antarctica): results of geophysical studies. Mar Geophys Res 29(2):135-158. doi:10. 1007/s11001-008-9051-z
Leitchenkov GL, Guseva YB, Gandyukhin VV, Ivanov SV, Safonova LV (2014) Structure of the Earth's crust and tectonic evolution history of the Southern Indian Ocean (Antarctica). Geotectonics 48(1):5-23

Masson DG, Harbitz CB, Wynn RB, Pedersen G, Løvholt F (2006) Submarine landslides: processes, triggers and hazard prediction. Philos Trans R Soc Lond A Math Phys Eng Sci 364(1845):2009-2039

Miller H, Henriet JP, Kaul N, Moons A (1990) A fine-scale stratigraphy of the eastern margin of the Weddell Sea. In: Bleil U, Thiede J (eds) Geological history of the polar oceans Arctic versus Antarctic. Kluwer Academic Publishers, Dordrecht, pp 131-161. doi:10.1007/978-94-009-2029-3_8

Peters LE, Anandakrishnan S, Alley RB, Winberry JP, Voigt DE, Smith AM, Morse DL (2006) Subglacial sediments as a control on the onset and location of two Siple Coast ice streams, West Antarctica. J Geophys Res Solid Earth (1978-2012) 111(B1)

Planke S, Rasmussen T, Rey SS, Myklebust R (2005) Seismic characteristics and distribution of volcanic intrusions and hydrothermal vent complexes in the Vøring and Møre basins. In: Geological Society, London, petroleum geology conference series. Geol Soc Lond 6:833-844. doi: 10.1144/0060833

Riedel S, Jokat W, Steinhage D (2012) Mapping tectonic provinces with airborne gravity and radar data in Dronning Maud Land, East Antarctica. Geophys J Int 189(1):414-427. doi:10.1111/j. 1365-246X.2012.05363.X

Rignot E, Mouginot J, Scheuchl B (2011) Ice flow of the Antarctic ice sheet. Science 333(6048):1427-1430

Roeser HA, Fritsch J, Hinz K (1996) The development of the crust off Donning Maud Land, East Antarctica. In: Storey BC, King EC, Livermore RA (Eds) Weddell Sea Tectonics and Gondwana Break-up. Geological Society Special Publication, vol 108, pp 243-264

Rogenhagen J, Jokat W, Hinz K, Kristoffersen Y (2004) Improved seismic stratigraphy of the Mesozoic Weddell Sea. Mar Geophys Res 25(3-4):265-282. doi:10.1007/s11001-005-1335-y

Shepard FP (1981) Submarine canyons: multiple causes and longtime persistence. AAPG Bull 65(6):1062-1077

Straub KM, Mohrig D (2009) Constructional canyons built by sheetlike turbidity currents: observations from offshore Brunei Darussalam. J Sediment Res 79(1):24-39

Weigelt E, Uenzelmann-Neben G, Gohl K, Larter RD (2012) Did massive glacial dewatering modify sedimentary structures on the Amundsen Sea Embayment shelf, West Antarctica? Glob Planet Change 92:8-16. doi:10.1016/j.glop;acha.2012.04.006

White R, McKenzie D (1989) Magmatism at rift zones: the generation of volcanic continental margins and flood basalts. J Geophys Res 94:7685-7729 